Original Research Paper

\title{
Technical Efficiency of Lobster (Panulirus sp) Farming in East Lombok Regency
}

\author{
Muhammad Nursan $^{1 *}$, Syarif Husni ${ }^{1}$, M. Yusuf ${ }^{1}$, Aeko Fria Utama FR ${ }^{1}$, Ni Made Nike \\ Zeamita Widiyanti ${ }^{1}$ \\ ${ }^{1}$ Agribisnis, Fakultas Pertanian, Universitas Mataram, Mataram, Indonesia;
}

\author{
Article History \\ Received : October $25^{\text {th }}, 2021$ \\ Revised : November $02^{\text {th }}, 2021$ \\ Accepted : November $10^{\text {th }}, 2021$ \\ Published : November $15^{\text {th }}, 2021$ \\ *Corresponding Author: \\ Muhammad Nursan, \\ Agribisnis/Fakultas Pertanian \\ Universitas Mataram, Mataram, \\ Indonesia; \\ Email: mnursan@yahoo.co.id
}

\begin{abstract}
East Lombok Regency is one of the centers for the development of aquaculture and the largest lobster seed producer in Indonesia. However, in terms of productivity, lobster cultivation is still relatively low due to the less optimal use of production factors and management in carrying out lobster rearing cultivation. The purpose of this study was to analyze the factors that affect the production of lobster rearing aquaculture and to analyze the level of technical efficiency and the factors that influence the technical inefficiency of lobster rearing aquaculture in East Lombok Regency. Descriptive research method was selected in this research. Cross section data was collected using a survey technique on 40 respondents who were selected by simple random sampling. The collected data was then analyzed using the Cobb-Douglas Stochastic Frontier production function with the Maximum Likelihood Estimator (MLE) method. The results showed that the production of lobster rearing aquaculture in East Lombok Regency was significantly influenced at the alpha level $5 \%$ by the variables of the number of cages, feed, number of family dependents and dummy species. The level of technical efficiency of lobster rearing cultivation is classified as efficient with a technical efficiency value of 0.94 . Then the factors that affect the inefficiency of lobster rearing business in East Lombok Regency include age, education level and training dummy.
\end{abstract}

Keywords: Lobster Farming; Maximum Likelihood Estimator (MLE) Method; Stochastic Frontier Production Function; Technical Efficiency and Inefficiency.

\section{Pendahuluan}

Salah satu subsektor pertanian yang menjadi sumber pertumbuhan perekonomian di indonesia adalah perikanan dan kelautan (Rizal et al., 2018; Sanger et al., 2019). Hal ini tidak lepas dari peran dan kontribusi dari subsektor perikanan dan kelautan yaitu sebagai penghasil pangan (Tibrani, 2018), penghasil bahan baku industri perikanan (Yonvitner, 2014; Krisnafi et al., 2017), penyedia lapangan kerja dan penyerap tenaga kerja (Triarso, 2012; Tibrani, 2018). Oleh karena itu maka pembangunan subsektor perikanan dan kelautan penting untuk dilakukan dan harus diprioritaskan oleh pemerintah daerah maupun pemerintah pusat. Salah satu strategi pengembangan perikanan yang perlu diterapkan adalah mengoptimalkan potensi sumberdaya perikanan untuk memperluas lapangan kerja (Nursan et al., 2020) dan usaha peningkatan produksi, pendapatan, serta ekspor produk perikanan (Lubis, 2012).

Salah satu komoditas perikanan dan kelautan yang penting untuk dikembangkan dan bernilai ekonomis adalah lobster. Lobster termasuk komoditas yang memiliki harga tinggi di pasar internasional (FAO, 2017) dan termasuk komoditas ekpor penting Indonesia dari jenis udang-udangan (Boesono et al., 2011). Harga pasar internasional lobster yang memiliki ukuran 1 kilogram dihargai mencapai US\$ 100 per kilogram dan untuk lobster dengan ukuran 300 gram - 1 Kilogram dihargai berkisar antara sebesar US\$ 50 - US\$ 80 per kilogram (Anh \& 
Jones, 2015). Mahalnya harga ekspor lobster tersebut tidak lepas dari tingginya permintaan lobster dari berbagai negara seperti Hongkong, China, Siangapura, dan Vietnam. Permintaan ekspor lobster terutama ke China meningkat drastis sejak awal tahun 1980-an (Mustafa, 2013). Adanya permintaan lobster yang tinggi dari negara-negara tersebut maka menjadi peluang dan pasar besar bagi lobster Indonesia.

Kebijakan mengembangkan usaha budidaya pembesaran lobster yang layak dan berkelanjutan dengan melakukan pemanenan lobster yang sesuai dengan ukuran pasar dapat dilakukan untuk memenuhi permintaan tersebut (Priyambodo et al., 2020). Peluang usaha budidaya lobster di Indonesia sangat besar dan menarik karena tingginya ketersediaan benih dari alam dan dapat dilakukan dengan teknologi sederhana dan modal yang tidak terlalu besar (Jones, 2010).

Provinsi Nusa Tenggara Barat merupakan salah satu wilayah pusat pengembangan budidaya lobster di Indonesia khususnya di perairan pulau Lombok yang merupakan salah satu lokasi penghasil benih lobster terbesar di Indonesia (Bahrawi, 2014). Sentra pengembangan lobster di Provinsi NTB ditetapkan di Kabupaten Lombok Timur tepatnya di Perairan Teluk Ekas dan Teluk Jukung Telong Elong Kecamatan Jerowaru Kabupaten Lombok Timur (DKP NTB, 2015). Hal ini dikarenakan tingginya potensi ketersediaan benih lobster di perairan teluk tersebut sehingga dapat dijadikan sebagai peluang untuk pengembangan aktivitas budidaya melalui usaha budidaya pembesaran lobster, sebagai mata pencaharian masyarakat pesisir (Erlania et al., 2016).

Usaha budidaya pembesaran lobster di Kabupaten Lombok Timur saat ini masih memiliki beberapa permasalahan. Dimana tingkat produktivitas usaha budidaya lobster yang masih tergolong rendah yaitu $50 \mathrm{~kg}$ per keramba dengan ukuran keramba jaring apung (KJA) $21 \mathrm{~m}^{3}$ sedangkan di Vietnam mencapai $57.7 \mathrm{~kg}$ per keramba (Priyambodo \& Sarifin, 2009). Selain itu, produktivitas lobster di Lombok hanya sebesar 2,8 $\mathrm{kg}$ per $\mathrm{m} 3$ dengan densitas sekitar 9 lobster per $\mathrm{m} 3$ untuk ukuran rata-rata lobster 300 gram, sedangkan produktivitas lobster di Vietnam sudah mencapai 3,64 kg per m3 dengan kisaran densitas sekitar 6 lobster per m3 untuk ukuran rata-rata lobster di atas 600 gram (Petersen \& Phuong, 2010).

Oleh karena itu, produktivitas budidaya pembesaran lobster di Kabupaten Lombok Timur perlu ditingkatkan dengan cara melakukan efisiensi usaha budidaya pembesaran lobster mengingat lobster merupakan komoditas perikanan unggulan di Kabupaten Lombok Timur. Rendahnya produktivitas budidaya pembesaran lobster tersebut disebabkan pengalokasian input-input produksi yang masih belum efisien seperti pakan, bibit dan tenaga kerja yang masih belum optimal. Dalam rangka mengatasi hal tersebut maka penggunaan inputinput dalam melakukan budidaya pembesaran lobster harus dilakukan dengan efisien agar produksi lobster dapat optimal. Menurut Mayashinta \& Firdaus (2013) menyatakan bahwa faktor produksi yang efisien dapat mengoptimalkan produksi. Tujuan dilakukan penelitian ini yaitu untuk menganalisis faktorfaktor apa saja yang mempengaruhi produksi usaha budidaya pembesaran lobster dan manganalisis efisiensi teknis dan faktor-faktor apa saja yang mempengaruhi tingkat inefisiensi teknis usaha budidaya pembesaran lobster di Kabupaten Lombok Timur.

\section{Bahan dan Metode}

Metode penelitian deskriptif kuantitatif dan kualitatif digunakan sebagai metode pada penelitian (Sugiono, 2017). Lokasi penelitian dilaksanakan di Telong Elong, Desa Jerowaru Kecamatan Jerowaru Kabupaten Lombok Timur yang dipilih secara purposive sampling atau dengan sengaja karena merupakan salah satu daerah penghasil lobster dan kawasan sentra produksi lobster. Waktu pelaksanaan penelitian mulai dari bulan Agustus sampai dengan bulan Nopember tahun 2021. Pengumpulan data menggunakan teknik survey dengan melakukan wawancara menggunakan kuesioner terhadap 40 responden yang ditentukan secara simple random sampling. Kemudian data yang diperoleh dianalisis berdasarkan tujuan penelitian. Fungsi produksi Cobb-Douglas stochastic frontier digunakan untuk menganalisis faktor-faktor yang mempengaruhi produksi lobster, tingkat efisiensi teknis dan faktor-faktor yang mempengaruhi inefisiensi teknis pada 
usaha budidaya pembesaran lobster. Persamaan fungsi produksi Cobb-Douglas stochastic frontier analysis (SFA) dari usaha budidaya pembesaran lobster di Kabupaten Lombok Timur dapat ditulis sebagai berikut (Coelli et al., 2005):

$\log \mathrm{Y}=\beta_{0}+\beta_{1} \log \mathrm{X}_{1}+\beta_{2} \log \mathrm{X}_{2}+\ldots+\beta_{6} \log \mathrm{X}_{6}+\left(v_{\mathrm{i}}-\mathrm{u}_{\mathrm{i}}\right)$

keterangan:

$\mathrm{Y} \quad=$ Produksi lobster $(\mathrm{kg})$

$\mathrm{X}_{1} \quad=$ Jumlah keramba (unit)

$\mathrm{X}_{2} \quad=$ Bibit lobster (ekor)

$\mathrm{X}_{3} \quad=$ Pakan $\left(\mathrm{kg} / \mathrm{m}^{3}\right)$

$\mathrm{X}_{4} \quad=$ Lama waktu pembesaran (hari)

$\mathrm{X}_{5} \quad=$ Tenaga kerja $(\mathrm{HKO})$

$\mathrm{X}_{6} \quad=$ Dummy spesies, $1=$ spesies lobster pasir dan mutiara, $0=$ spesies lobster pasir atau mutiara

$\beta_{0} \quad=$ Konstanta

$\beta_{\mathrm{j}} \quad=$ Nilai atau koefisien parameter $\mathrm{j}=1,2,3,4,5$, dan 6

$\mathrm{v}_{\mathrm{i}}=$ Variabel acak eksternal yang sebarannya simetris dan menyebar $\operatorname{normal}\left(\mathrm{v}_{\mathrm{i}}-\mathrm{N}\left(0, \sigma_{v}^{2}\right)\right)$

$\mathrm{u}_{\mathrm{i}} \quad=$ Variabel acak internal diasumsikan mempengaruhi tingkat inefisiensi teknis yang sebarannya bersifat setengah normal $\left(\mathrm{u}_{\mathrm{i}}-\mathrm{N}\left(0, \sigma_{u}^{2}\right)\right)$.

Kemudian untuk mengukur tingkat efisiensi teknis digunakan persamaan sebagai berikut (Coelli et al., 2005):

$$
T E=\frac{E\left(Y / U_{i}, X_{1}, X_{2}, X_{3}, X_{4}, X_{5}, X_{6}\right)}{E\left(Y^{*} / U_{i}=0, X_{1}, X_{2}, X_{3}, X_{4}, X_{5}, X_{6}\right)}
$$

keterangan:

TE = efisiensi teknis

$E\left(Y / U_{i}, X_{i}\right) \quad=$ output observasi

$E\left(Y^{*} / U_{i}=0, X_{i}\right)=$ output batas (frontier)

Kisaran untuk nilai efisiensi teknis yaitu berada antara $0 \leq \mathrm{TE} \leq 1$. Dikatakan efisien jika memiliki nilai $\geq 0.80$ dan belum efisien nilainya $<0.80$.

Kemudian model efek inefisiensi teknis oleh Coelli et al., (2005) digunakan untuk mengukur tingkat inefisiensi teknis usaha budidaya pembesaran lobster di Kabupaten Lombok Timur. Variabel $u_{i}$ sebagai efek dari inefisiensi teknis pada usaha budidaya pembesaran lobster diasumsikan terdistribusi setengah normal dan bebas dengan $\mathrm{N}\left(\mathrm{u}_{\mathrm{i}}, \sigma^{2}\right)$.
Adapun persamaan efek inefisiensi teknis $\left(u_{i}\right)$ yang digunakan pada penelitian ini yaitu sebagai berikut:

$U_{i}=\delta_{0}+\delta_{1} Z_{1}+\delta_{2} Z_{2}+\delta_{3} Z_{3}+\delta_{4} Z_{4}+\delta_{5} Z_{5}+\omega_{\mathrm{i}}$ keterangan:

$U_{i}=$ efek inefisiensi teknis

$Z_{1}=$ umur (tahun)

$Z_{2}=$ tingkat pendidikan (tahun)

$Z_{3}=$ pengalaman budidaya (tahun)

$Z_{4}=$ jumlah tanggungan keluarga (orang)

$Z_{5}=$ ikut Penyuluhan dan pelatihan (ikut=1 dan tidak ikut $=0$ )

Nilai koefisien penduga yang diharapkan yaitu $\delta_{0}>0, \delta_{1}>0, \delta_{2}, \delta_{3}, \delta_{4}, \delta_{5}<0$.

Nilai parameter faktor-faktor yang mempengaruhi fungsi produksi Cobb Douglas stochastic frontier dan inefisiensi teknis diestimasi secara bersamaan dengan Program Frontier 4.1 sebanyak 2 tahap. Tahap pertama dilakukan penaksiran nilai parameter $\beta_{j}$ dengan menggunakan metode OLS, kemudian tahap kedua menggunakan metode Maximum Likelihood (MLE) untuk menduga nilai parameter keseluruhan $\beta_{0}, \beta_{j}$, Tingkat alpha $(\alpha)$ yang digunakan yaitu pada level 5 persen. Hasil analisis dari Program Frontier 4.1 dapat, memberikan nilai perkiraan varians parameter sebagai berikut (Aigner et al., 1977; Coelli et al., 2005):

$$
\begin{aligned}
& \sigma^{2}=\sigma_{v}^{2}+\sigma_{u}^{2} \\
& \gamma=\frac{\sigma_{u}^{2}}{\sigma_{v}^{2}}
\end{aligned}
$$

Parameter varians ini menghasilkan nilai gamma $(\gamma)$ dengan kisaran nilai $0 \leq \gamma \leq 1$. Nilai gamma $(\gamma)$ diartikan sebagai besarnya kontribusi efek inefisiensi teknis terhadap efek residual total.

\section{Hasil dan Pembahasan}

\section{Karakteristik Responden}

Berdasarkan hasil analisis karakteristik responden diperoleh rata-rata umur responden sebesar 44 tahun. Persentase umur tertinggi pada kisaran umur 35-44 tahun yaitu sebanyak 18 orang atau sebesar 45 persen. Hal ini menunjukkan bahwa pembudidaya dalam mengelola usaha budidaya pembesaran lobster 
dapat dilakukan dengan baik karena berada pada umur produktif. Semakin muda umur maka akan lebih produktif, inovatif termotivasi untuk bekerja (Musafiri, 2016)

Tingkat pendidikan formal responden ratarata sebesar 8 tahun atau pada tingkat Sekolah Menengah Pertama. Namun, persentase tingkat pendidikan tertinggi masih pada tingkat Sekolah Dasar (SD) yakni sebanyak 13 orang atau sebesar 32.5 persen. Kemudian, untuk tingkatan SMA dan perguruan tinggi (S1) di daerah penelitian juga cukup tinggi. Hal ini mengartikan bahwa pendidikan dapat berkaitan dengan pengetahuan dan keterampilan pembudidaya dalam mengadopsi teknologi dan inovasi di bidang budidaya lobster.

Pengalaman usaha budidaya lobster responden juga dapat menjadi penentu dalam mengadopsi teknologi dan inovasi untuk melakukan usaha budidaya pembesaran lobster. Semakin berpengalaman responden maka akan terampil dalam melakukan usaha budidaya pembesaran lobster dan dapat memilih teknologi dan inovasi yang sesuai. Responden dalam melakukan usaha budidaya pembesaran lobster di daerah penelitian memiliki pengalaman ratarata sebanyak 7 tahun. Responden dengan pengalaman usaha 1-5 tahun memiliki persentasi terbanyak yaitu sebesar 57.5 persen. Kemudian untuk jumlah tanggungan responden rata-rata pada wilayah penelitian sebesar 4 orang dengan persentase terbanyak pada kisaran 3-4 orang yaitu sebesar 65 persen. Adapun secara rinci karakteristik responden yaitu sebagai berikut.

Tabel 1. Sebaran karakteristik responden usaha budidaya pembesaran lobster di Kabupaten Lombok Timur tahun 2021

\begin{tabular}{|c|c|c|c|}
\hline \multirow[t]{2}{*}{ No } & \multirow{2}{*}{ Kisaran } & \multicolumn{2}{|c|}{$\begin{array}{c}\text { Pembudidaya } \\
\text { Lobster }\end{array}$} \\
\hline & & $\begin{array}{l}\text { Jumlah } \\
\text { (orang) }\end{array}$ & $\begin{array}{c}\text { Persentase } \\
(\%)\end{array}$ \\
\hline 1 & Umur (Tahun) & & \\
\hline & a. $25-34$ & 5 & 12.5 \\
\hline & b. $35-44$ & 18 & 45 \\
\hline & c. $45-54$ & 11 & 27.5 \\
\hline & d. 55-64 & 5 & 12.5 \\
\hline & e. $>64$ & 1 & 2.5 \\
\hline & Rata-rata & $40(44)$ & 100 \\
\hline 2 & Pendidikan Fo & (tahun) & \\
\hline
\end{tabular}

\begin{tabular}{|c|c|c|c|}
\hline & $\begin{array}{l}\text { a. Tidak Pernah } \\
\text { Sekolah }(0)\end{array}$ & 4 & 10 \\
\hline & $\begin{array}{l}\text { b. Sekolah } \\
\text { Dasar (1-6) }\end{array}$ & 13 & 32.5 \\
\hline & c. Sekolah & & \\
\hline & Menegah & 11 & 27.5 \\
\hline & Pertama (7-9) & & \\
\hline & d. Sekolah & & \\
\hline & Menengah & 9 & 22.5 \\
\hline & Atas (10-12) & & \\
\hline & 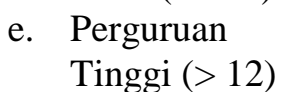 & 3 & 7.5 \\
\hline & Rata-rata & $40(8)$ & 100 \\
\hline 3 & \multicolumn{3}{|c|}{ Tingkat Pengalaman (tahun) } \\
\hline & a. $1-5$ & 23 & 57.5 \\
\hline & b. $6-10$ & 11 & 27.5 \\
\hline & c. $>10$ & 6 & 15 \\
\hline & Rata-rata & $40(7)$ & 100 \\
\hline 4 & \multicolumn{3}{|c|}{ Jumah Tanggungan Keluarga (Orang) } \\
\hline & $1-2$ & 9 & 22.5 \\
\hline & $3-4$ & 26 & 65 \\
\hline & $>4$ & 5 & 12.5 \\
\hline & Rata-rata & $40(4)$ & 100 \\
\hline
\end{tabular}

Sumber: Data Primer Diolah (2021)

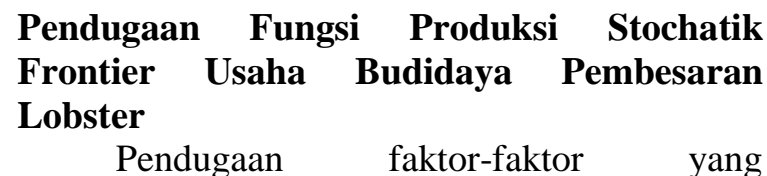
mempengaruhi produksi usaha pembesaran lobster di Kabupaten Lombok Timur dilakukan dengan menggunakan model fungsi produksi Cobb-Douglas Stochatik Frontier dengan Metode maximum likelihood estimator (MLE) menggunakan Program Frontier 4.1. Adapun secara rinci nilai pendugaan faktor-faktor yang mempengaruhi produksi usaha budidaya pembesaran lobster di Kabupaten Lombok Timur dapat dilihat pada tabel berikut ini.

Tabel 2. Hasil analisis fungsi produksi Cobb Douglas stochastic frontier usaha budidaya pembesaran lobster di Kabupaten Lombok Timur menggunakan Metode MLE Tahun 2021

\begin{tabular}{lccc}
\hline Variabel & Koefisien & $\begin{array}{c}\text { Standar- } \\
\text { error }\end{array}$ & t-ratio \\
\hline $\begin{array}{l}\text { Konstanta } \\
\begin{array}{l}\text { Jumlah } \\
\text { Keramba } \\
\left(\mathrm{X}_{1}\right)\end{array}\end{array}$ & 1,493 & 0,714 & 2.091 \\
\hline
\end{tabular}




\begin{tabular}{lccc}
\hline Bibit $\left(\mathrm{X}_{2}\right)$ & 0.020 & 0,175 & 0.115 \\
Pakan $\left(\mathrm{X}_{3}\right)$ & $-0,271^{*}$ & 0,134 & $-2,030$ \\
$\begin{array}{l}\text { Lama } \\
\text { Waktu }\end{array}$ & & & \\
$\begin{array}{l}\text { Pembesaran } \\
\left(\mathrm{X}_{4}\right)\end{array}$ & 0,065 & 0,241 & 0.272 \\
$\begin{array}{l}\text { Tenaga } \\
\text { Kerja }\left(\mathrm{X}_{5}\right)\end{array}$ & 0,042 & 0,175 & 0.241 \\
$\begin{array}{l}\text { Dummy } \\
\text { Sepesies }\end{array}$ & $0,09^{*}$ & 0,048 & 1,902 \\
$\begin{array}{l}\left.\mathrm{X}_{6}\right) \\
\text { Sigma- }\end{array}$ & $0,012^{*}$ & 0,002 & 5,29 \\
square $\left(\sigma^{2}\right)$ & 0,057 & 0,169 & 0,339 \\
$\begin{array}{l}\text { Gamma }(\gamma) \\
\text { L-R test }\end{array}$ & 8,908 & & \\
\hline Keterangan: & & & \\
\hline
\end{tabular}

Keterangan:*nyata pada taraf 5\%

Berdasarkan hasil analisis pada Tabel 2, nilai sigma square $\left(\sigma^{2}\right)$ fungsi produksi Cobb Douglas stochastic frontier usaha budidaya pembesaran lobster yaitu sebesar 0,012. Nilai ini sesuai dengan harapan karena lebih besar dari nol dan berpengaruh nyata pada taraf alpha 5 persen. Ini berarti model yang digunakan pada penelitian ini sudah tepat karena faktor internal (ui) dan faktor eksternal (vi) sesuai dengan asumsi yaitu menyebar normal dan bebas (Ojo et al., 2009). Nilai Sigma square $\left(\sigma^{2}\right)$ menunjukkan jumlah varians dari faktor internal (ui) dan faktor eksternal (vi). Kemudian untuk nilai gamma $(\gamma)$ yaitu sebesar 0.057 dan tidak berpengaruh nyata pada taraf alpha 5 persen. Ini berarti bahwa variasi atau perbedaan hasil produksi usaha budidaya pembesaran lobster di Kabupaten Lombok Timur lebih dominan disebabkan oleh faktor-faktor stochastic seperti pengaruh cuaca, iklim, bencana alam, serangan hama, penyakit dan lainnya. Nilai Sigma square $\left(\sigma^{2}\right)$ yang rendah ini juga selaras dengan temuan pada penelitian Susanti et al., (2017) dengan nilai Nilai Sigma square $\left(\sigma^{2}\right)$ sebesar 0,003 dan memiliki pengaruh tidak nyata pada taraf alpha 5 persen.

Nilai ratio generalized-likelihood (LR) diperoleh sebesar 8.91 lebih kecil dari nilai tabel perbandingan Kodde dan Palm dengan restriksi 7 yaitu sebesar 13.40 dan tidak berpengaruh nyata pada taraf alpha 5 persen. Ini berarti bahwa efek efisiensi dan inefisiensi teknis tidak memiliki pengaruh pada perbedaan produksi diantara pembudidaya dalam melakukan usaha budidaya pembesaran lobster di Kabupaten Lombok Timur.
Hasil analisis faktor-faktor usaha budidaya pembesaran lobster di Kabupaten Lombok Timur menggunakan fungsi produksi Cobb Douglas stochastic frontier pada Tabel 2 menunjukkan bahwa variabel jumlah keramba, bibit, lama waktu pembesaran, tenaga kerja dan dummy spesies memiliki nilai koefisien yang positif sedangkan variabel pakan memiliki nilai koefisien negatif. Variabel-variabel yang berpengaruh nyata pada taraf alpha 5 persen yaitu jumlah keramba, pakan dan dummy spesies.

Variabel jumlah keramba jaring apung (KJA) berpengaruh sangat nyata pada taraf 5 persen terhadap produksi usaha budidaya pembesaran lobster di Kabupaten Lombok Timur. nilai koefisien atau elastistas variabel jumlah kerambah paling tinggi yaitu sebesar 0,732 , yang berarti jika jumlah KJA meningkat sebesar 1 persen maka produksi usaha budidaya pembesaran lobster akan meningkat sebesar 0,732 persen.

Variabel bibit lobster memiliki nilai koefisien atau elastisitas yang positif yaitu sebesar 0,020. Ini artinya jika input bibit dinaikkan sebesar 1 persen maka produksi lobster akan meningkat sebesar 0,020 persen. Namun variabel bibit lobster ini tidak memiliki pengaruh nyata terhadap produksi usaha budidaya pembesaran lobster pada taraf alpha 5 persen.

Pakan berpengaruh nyata terhadap produksi usaha budidaya pembesaran lobster pada taraf 5 persen dan memiliki nilai koefisien atau elastistas sebesar -0,271. Ini berarti bahwa jika penggunaaan input pakan dinaikan sebesar 1 persen produksi usaha budidaya pembesaran lobster menurun sebesar 0.271 persen. Pakan yang paling banyak diberikan oleh pembudidaya di daerah penelitian adalah pakan berupa ikan rucah. Menurut Priyambodo \& Sarifin (2009). pakan ikan rucah tidak ideal digunakan sebagai pakan lobster karena kandungan gizi yang kurang dan menghasilkan lobster dewasa yang berpigmentasi pucat.

Kemudian untuk variabel lama pembesaran lobster memiliki nilai koefisien atau elastisitas positif, namun tidak memiliki pengaruh nyata pada taraf alpha 5 persen. Nilai koefisien atau elastisitas variabel lama waktu pembesaran yaitu sebesar 0,065 . Ini berarti jika lama waktu pembesaran lobster dinaikkan sebesar 1 persen maka produksi usaha budidaya 
pembesaran lobster naik sebesar 0,065 persen. Variabel tenaga kerja juga memiliki nilai koefisien atau elastistas positif yaitu sebesar 0,042 , yang berarti penambahan tenaga kerja sebesar 1 persen dapat meningkatkan produksi usaha budidaya pembesaran lobster sebesar 0,042 persen. Akan tetapi variabel tenaga kerja juga tidak berpengaruh nyata pada taraf alpha 5 persen.

Variabel dummy spesies memiliki pengaruh yang positif dan nyata pada alpha 5 persen. Nilai koefisien atau elastisitas dummy spesies yaitu sebesar 0,09. Ini berarti bahwa pembudidaya yang membudidayakan 2 jenis lobster yaitu pasir dan mutiara dapat lebih meningkatkan produksi sebesar 0,09 persen dibandingkan dengan pembudidaya yang hanya membudidayakan 1 jenis lobster.

\section{Tingkat Efisiensi Teknis Usaha Budidaya Pembesaran Lobster}

Tingkat efisiensi teknis berkaitan dengan tingkat keterampilan dan manajemen pembudidaya dalam melakukan usaha budidaya pembesaran lobster di Kabupaten Lombok Timur. Adapun hasil analisis efisiensi teknis dapat dilihat pada tabel berikut ini.

Tabel 3. Tingkat efisiensi teknis usaha budidaya pembesaran lobster di Kabupaten Lombok Timur Tahun 2021

\begin{tabular}{lcc}
\hline $\begin{array}{c}\text { Tingkat } \\
\begin{array}{c}\text { Efisiensi } \\
\text { Teknis } \\
(\%)\end{array}\end{array}$ & $\begin{array}{c}\text { Pumlah } \\
\text { (orang) }\end{array}$ & $\begin{array}{c}\text { Persentase } \\
(\%)\end{array}$ \\
\hline $0-10$ & 0 & 0 \\
$11-20$ & 0 & 0 \\
$21-30$ & 0 & 0 \\
$31-40$ & 0 & 0 \\
$41-50$ & 0 & 0 \\
$51-60$ & 0 & 0 \\
$61-70$ & 0 & 0 \\
$71-80$ & 2 & 5 \\
$81-90$ & 9 & 22,5 \\
$91-100$ & 29 & 72,5 \\
\hline Jumlah & 40 & 100 \\
\hline Maksimum & 0.99 & \\
Minimum & 0.73 & \\
Rata-rata & 0.94 & \\
\hline
\end{tabular}

Berdasarkan data pada tabel menunjukkan bahwa efisiensi teknis usaha budidaya pembesaran lobster di Kabupaten Lombok Timur sudah tergolong efisien dengan nilai rata-rata sebesar 0,94 dengan nilai efisiensi teknis minimum sebesar 0,73 dan nilai maksimum 0,99 . Jika nilai efisiensi teknis $\geq 0.80$ maka sudah tergolong efisien (Nursan, 2015; Fadwiwati, 2013). Nilai efisiensi teknis pada penelitian ini lebih tinggi dibandingkan hasil penelitian Susanti et al., (2017) yang memperoleh nilai efisiensi teknis sebesar 0,91 .

Nilai efisiensi teknis yang sebesar 0.94, mengindikasikan bahwa pembudidaya lobster dalam melakukan usaha bididaya pembesaran lobster pada tingkat teknologi dan input yang tersedia masih dapat meningkatkan efisiensi teknis sebesar 6,06 persen (1-0.94/0.99). Adanya tingkat efisiensi teknis yang berbeda diantara pembudidaya sangat berkaitan erat dengan adanya tingkat penggunaan teknologi serta manajemen usaha budidaya pembesaran lobster.

\section{Faktor-faktor Yang Mempengaruhi Inefisiensi Teknis Usaha Budidaya Pemebesaran Lobster}

Faktor-faktor yang mempengaruhi inefisiensi teknis usaha budidaya pembesaran lobster di Kabupaten Lombok Timur dianalisis juga secara simultan dengan menggunakan fungsi produksi Cobb-Douglas stochastic fronter. Adapun secara rinci hasil analisis faktorfaktor yang mempengaruhi inefisiensi teknis usaha budidaya pembesaran lobster disajikan pada tabel berikut ini:

Tabel 4. Hasil analisis faktor-faktor yang mempengaruhi inefisiensi teknis usaha budidaya pembesaran lobster di Kabupaten Lombok Timur Tahun 2021

\begin{tabular}{|c|c|c|c|}
\hline Variabel & Koefisien & $\begin{array}{l}\text { Standar- } \\
\text { error }\end{array}$ & $\begin{array}{c}\mathrm{t}- \\
\text { ratio }\end{array}$ \\
\hline konstanta & 0,413 & 0,219 & 1,890 \\
\hline $\begin{array}{l}\text { umur petani } \\
\left(Z_{l}\right)\end{array}$ & $-0,006^{*}$ & 0,004 & $-1,447$ \\
\hline $\begin{array}{l}\text { pendidikan } \\
\left(Z_{2}\right)\end{array}$ & 0,009 & 0,009 & 1.057 \\
\hline $\begin{array}{l}\text { pengalaman } \\
\text { petani }\left(Z_{3}\right)\end{array}$ & -0.004 & 0,008 & $-0,544$ \\
\hline
\end{tabular}




\begin{tabular}{|c|c|c|c|}
\hline $\begin{array}{l}\text { Jumlah } \\
\text { Tanggungan } \\
\left(Z_{4}\right)\end{array}$ & $-0,032 *$ & 0,026 & $-1,207$ \\
\hline $\begin{array}{l}\text { Dummy } \\
\text { pelatihan }\left(Z_{5}\right)\end{array}$ & $-0,174 *$ & 0,065 & $-2,654$ \\
\hline
\end{tabular}

Dari hasil analisis pada tabel 4 diperoleh variabel yang memiliki pengaruh nyata terhadap inefisiensi teknis usaha budidaya pembesaran lobster pada alpha 5 persen yaitu variabel umur, jumlah tanggungan dan dummy pelatihan yang memiliki tanda negatif. Sedangkan variabel pendidikan dan jumlah pengalaman tidak memiliki pengaruh nyata pada taraf alpha 5 persen.

Nilai koefisien atau elastisitas variabel umur sebesar -0.006 dan berpengaruh nyata terhadap inefisiensi usaha budidaya pembesaran lobster di Kabupaten Lombok Timur pada taraf alpha 5 persen. Ini artinya bahwa kenaikan usia pembudidaya lobster sebesar 1 persen maka dapat menurunkan inefisiensi teknis usaha budidaya pembesaran lobster sebesar 0.006. kemudian variabel jumlah tanggungan keluarga juga memiliki pengaruh nyata pada taraf alpha 5 persen terhadap inefisiensi teknis usaha budidaya pembesaran lobster dengan nilai koefisien sebesar -0,032. Ini berarti bahwa jika jumlah tanggungan keluarga pembudidaya bertambah 1 persen maka dapat menurunkan inefisiensi teknis usaha budidaya pembesaran lobster sebesar 0,032 persen. Jumlah tanggungan keluarga berkaitan erat dengan motivasi kerja pembudidaya lobster.

Kemudian variabel dummy pelatihan memiliki nilai koefisien atau elastisitas sebesar 0.174 dan memiliki pengaruh nyata pada taraf alpha 5 persen. Pembudidaya yang pernah ikut pelatihan lebih dapat menurunkan tingkat inefisiensi teknis sebesar 0.174 dibandingkan dengan pembudidaya yang tidak pernah ikut pelatihan atau penyuluhan budidaya pembesaran lobster.

\section{Kesimpulan}

Dari hasil dan pembahasan penelitian maka dapat disimpulkan bahwa: 1) Produksi usaha budidaya pembesaran lobster di Kabupaten Lombok Timur dipengaruhi secara nyata oleh variabel jumlah keramba, pakan, dan dummy spesies lobster. 2) Tingkat efisiensi teknis usaha budidaya pembesaran lobster di Kabupaten Lombok Timur sudah tergolong efisien dengan nilai rata-rata sebesar 0.94. 3) Faktor-faktor yang mempengaruhi tingkat inefisiensi teknis usaha budidaya pembesaran lobster di Kabupaten Lombok Timur meliputi variabel umur, jumlah tanggungan keluarga dan dummy pelatihan. Kegiatan pelatihan atau penyuluhan kepada pembudidaya yang melakukan usaha budidaya pembesaran lobster sangat penting dan perlu diperbanyak karena terbukti meningkatkan efisiensi produksi lobster. Pemerintah perlu memberikan bantuan sarana produksi seperti keramba jaring apung (KJA) dan pakan berkualitas untuk dapat membantu petani menigkatkan produksi dan pendapatan usaha.

\section{Ucapan Terima Kasih}

Terima kasih disampaikan kepada para pihak yang telah membantu pelaksanaan penelitian ini khususnya kepada LPPM Universitas Mataram dan Fakultas Pertanian Universitas Mataram yang telah memberikan dukungan pendanaan dalam melakukan penelitian ini.

\section{Referensi}

Aigner, D., Lovell, C., \& Schmidt, P. (1977). Formulation and Estimation Stochastic Frontier Production Function Model. Journal of Econometrics, 5(6), 21-37.

Anh, T. \& Jones, C. (2015). Lobster seed fishing, handling and transport in Vietnam. Chapter 2.4. In: Jones, C.O. (Ed.), Spiny lobster aquaculture development in Indonesia, Vietnam and Australia. Proceedings of the International Lobster Aquaculture Symposium Held in Lombok, Indonesia, 22-25 April 2014., 31-35.

Bahrawi, S. (2014). Improving Puerelus catch in Indonesia. International Lobster Symposium.

Boesono, H., Anggoro, S., \& Bambang, A. N. (2011). Laju Tangkap dan Analisis Usaha Penangkapan Lobster (Panulirus Sp) dengan Jaring Lobster (Gillnet 
Monofilament). Jurnal Saintek Perikanan, 7(1), 77-87.

Coelli, T., Rao, D., \& Battese, G. (2005). An Introduction to Efficiency and Productivity Analysis. Second Edition. Springer.

DKP NTB (2015). Kajian/Analisis Pengelolaan Benih Lobster (Panulirus spp.) di Provinsi Nusa Tenggara Barat. Dinas Kelautan dan Perikanan Provinsi Nusa Tenggara Barat.

Erlania, Radiarta, I. N., \& Haryadi, J. (2016). Status Pengelolaan Sumberdaya Benih Lobster Untuk Mendukung Perikanan Budidaya: Studi Kasus Perairan Pulau Lombok. Jurnal Kebijakan Perikanan Indonesia (JKPI), 8(2), 85-96.

Fadwiwati, A. (2013). Pengaruh penggunaan varietas unggul terhadap efisiensi, pendapatan dan distribusi pendapatan petani jagung di Provinsi Gorontalo. Institut Pertanian Bogor.

FAO (2017). Globefish Monthly Trade Statistics. Food and Agriculture Organization of United States.

Jones, C. (2010). Tropical spiny lobster aquaculture development in Vietnam, Indonesia and Australia. J. Mar. Biol. Ass., 52(2), 304-315.

Krisnafi, Y., Iskandar, B. H., Wisudo, S. H., \& Haluan, J. (2017). Penentuan Prioritas Wilayah Kerja Untuk Peningkatan Pengawasan Perikanan di WPP NRI 711. Marine Fisheries, 8(2), 211-221.

Lubis, E. (2012). Pelabuhan Perikanan. IPB Press.

Mayashinta, W., \& Firdaus, M. (2013). FaktorFaktor yang Memengaruhi Total Factor Productivity Industri Pertanian Indonesia Periode 1981-2010. Jurnal Manajemen \& Agribisnis, 10(2), 90-97.

Musafiri, I. (2016). Effects of Population Growth on Smallholder Farmers' Productivity and
Consumption in Rwanda: A Long-term Analysis. Asian Journal of Agricultural Extension, Economics \& Sociology, 12(4), $1-11$.

https://doi.org/10.9734/ajaees/2016/2769 3

Mustafa, A. (2013). Budidaya Lobster (Panulirus sp.) di Vietnam dan Aplikasinyadi Indonesia. Media Akuakultur, 8(2), 73-82.

Nursan, M. (2015). Efisiensi dan Daya Saing Usahatani Jagung Pada Lahan Kering dan Sawah di Kabupaten Sumbawa [Institut Pertanian Bogor]. https://repository.ipb.ac.id/handle/123456 $789 / 74832$

Nursan, M., Nabilah, S., \& Sari, N. M. W. (2020). Potensi dan Strategi Pengembangan Kawasan Minapolitan Kertasari Kabupaten Sumbawa Barat. Jurnal Ilmiah Membangun Desa Dan Pertanian (JIMDP), 5(6), 192-201.

Ojo, M., Mohammed, U., Ojo, A., \& Olaleye, R. (2009). Return to Scale and Scale, Determinants of Farm Level Technical Inefficiency Among Small Yam Based Farmers in Niger State, Nigeria: implication for food security Development. International Journal of Agricultural Economics and Rural Development, 2(1), 43-51.

Petersen, E. \& Phuong, T. (2010). Tropical Spiny Lobster (Panulirus ornatus) Farming in Vietnam-Bioeconomics and Perceived Constraints to Development. Aquaculture Research, 41(10), e634-e642.

Priyambodo, B, \& Sarifin (2009). Lobster Aquaculture Industry in Eastern Indonesia: Present Status and Prospects In Spiny Lobster Aquaculture in Asia-Pacific Region. Australian Centre for International Agricultural Research Prosiding, 36-45.

Priyambodo, B, Jones, C. M., \& Sammut, J. (2020). Assessment of the lobster puerulus ( Panulirus homarus and Panulirus ornatus 
, Decapoda: Palinuridae ) resource of Indonesia and its potential for sustainable harvest for aquaculture. Aquaculture, 528(735563), $1-17$. https://doi.org/10.1016/j.aquaculture.2020 .735563

Rizal, A., Iskandar, Herawati, H., \& Dewanti, L. (2018). Potret dan Review: Strategi Pembangunan Perikanan dan Kelautan. Unpad Press.

Sanger, C. L. M., Jusuf, A., \& Andaki, J. A. (2019). Analisis Orientasi Kewirausahaan Nelayan Tangkap Skala Kecil Dengan Alat Tangkap "Jubi" di Kelurahan Batulubang Kecamatan Lembeh Selatan Kota Bitung. AKULTURASI: Jurnal Ilmiah Agrobisnis Perikanan, 7(1), 10951102.

https://doi.org/https://doi.org/10.35800/ak ulturasi.7.1.2019.24401

Sugiono (2017). Metode Penelitian Kuantitatif, Kualitatif, dan $R \& D$. Alfabeta.

Susanti, E. N., Oktaviani, R., Hartoyo, S., \& Priyarsono, D. S. (2017). Efisiensi Teknis Usaha Pembesaran Lobster di Pulau Lombok, Provinsi Nusa Tenggara Barat. Jurnal Manajemen \& Agribisnis, 14(3), 230-239.

https://doi.org/http://dx.doi.org/10.17358/ jma.14.3.230

Tibrani (2018). Peranan Subsektor Perikanan Dalam Menunjang Perekonomian Kabupaten Kampar Provinsi Riau. Jurnal Agribisnis, 20(2), 206-217.

Triarso, I. (2012). Potensi dan Peluang Pengembangan Usaha Perikanan Tangkap di Pantura Jawa Tengah. Jurnal Saintek Perikanan, 8(1), 65-73.

Yonvitner (2014). Bahan Baku: Urat Nadi Industri Pengolahan Perikanan Mikro Kecil dan Menengah. Jurnal Risalah Kebijakan Pertanian Dan Lingkungan, 1(3), 187-191. 